\title{
DI BAWAH BAYANG-BAYANG IBUKOTA: PENATAAN DAERAH DI PROVINSI BANTEN DARI ZAMAN KOLONIAL SAMPAI ZAMAN REFORMASI
}

\author{
Radjimo Sastro Wijono \\ Masyarakat Sejarawan Indonesia Cabang Banten
}

Alamat korespondensi: radjimo@gmail.com

Diterima/ Received: 1 Oktober 2017 ; Disetujui/ Accepted: 30 Oktober 2017

\begin{abstract}
This article discusses regional reforms that took place in Indonesia's youngest province of Banten from the Dutch colonial until reform era. Regional reforms which heppened in this area is very interesting to learn. Political-economic situation as main factor of regional reform in Banten. Moreover, regulation changes of Banten have occurred several times since traditional ruler (sultanate) continued to the colonial government in the 19th century. During the Dutch colonial period, the Governor General Daendles reformed Banten into three districts i.e. Banten Hulu, Banten Hilir and Anyer. Meanwhile, during the British colonial period Banten was divided into four districts i.e. Banten Lor, Banten Kulon, Banten Tengah, and Banten Kidul. Territorial policy reform has certainly had an impact in political, economic and cultural aspects. Regulation of regional arrangement in Banten is not only influenced by political and economic shadow situation from Jakarta and Bandung, but also put much consideration on ecological aspect and public interest of multicultural society.
\end{abstract}

Keywords: Territorial Reforms; Social Changes; Banten in the Cross-Orde.

\section{Abstrak}

Artikel ini membahas reformasi wilayah yang berlangsung di provinsi termuda di Indonesia yaitu Banten sejak zaman penjajahan Belanda sampai masa reformasi. Reformasi wilayah yang terjadi di daerah ini sangat menarik untuk dipelajari. Situasi politik-ekonomi merupakan faktor utama terjadinya reformasi wilayah di Banten. Dengan menggunakan metode sejarah, perubahan pengaturan wilayah Banten diketahui telah terjadi beberapa kali sejak masa penguasa tradisional (kesultanan) yang dilumpuhkan oleh pemerintah kolonial pada abad ke-19 hingga masa reformasi. Pada masa kolonial, Gubernur Jenderal Daendles mereformasi wilayah Banten menjadi tiga kabupaten yaitu Banten Hulu, Banten Hilir, dan Anyer. Sementara itu, pada masa kolonial Inggris wilayah Banten dibagi menjadi empat kabupaten yaitu Banten Lor, Banten Kulon, Banten Tengah, dan Banten Kidul. Perubahan kebijakan reformasi teritorial itu tentu saja membawa dampak dalam bidang politik, ekonomi, dan budaya. Regulasi penataan wilayah di Banten tidak hanya dipengaruhi oleh bayang-bayang situasi politik dan ekonomi dari Jakarta dan Bandung, tetapi juga berdasar pada aspek ekologis serta kepentingan umum masyarakat yang multikultur.

Kata Kunci: Penataan Wilayah; Perubahan Sosial; Banten dalam Lintasan Orde.

\section{PENDAHULUAN}

Setiap tahun pada September, terdapat dua peristiwa besar yang menjadi tema utama pembicaraan masyarakat, bahkan menjadi komoditas Peristiwa Gestapu dan Peristiwa 11 September 1999. Dua peristiwa sejarah itu tidak jarang menjadi bahan perdebatan pada sebuah 
pembicaraan. Peristiwa Gestapu misalnya, (masih) selalu saja ada dua orang, atau dua kelompok atau lebih yang memiliki pendapat berbeda. Sebenarnya, akar perbedaan dari perdebatan mereka adalah sejarah, peristiwa masa lalu (apa, kapan, di mana, siapa, mengapa dan bagaimana). Kebauran peristiwa masa lalu itu kemudian dimanfaatkan sebagai komoditas politik, menyalahkan lawan dan mencari kawan. Boleh dikatakan, terlepas dari kepentingan politik yang bermain, seandainya peristiwa yang terjadi pada pagi dini hari pada 30 September 1965 di Jakarta Timur telah jelas, mungkin tidak ada lagi kisruh masalah peristiwa masa lalu itu. Lebih parahna, peristiwa yang berlangsung tidak lebih dari 10 jam itu telah membawa tragedi dan derita yang sampai sekarang masih belum hilang di tanah air ini.

Kontroversi dalam sejarah memang tidak dapat dielakkan. Lantas, di mana sejarah yang benar? Menurut Taufik Abdullah, sejarah sebagai gambaran masa lalu yang dianggap signifikan (benar) adalah milik masyarakat, bukan milik monopoli sejarawan atau penguasa (Abdullah dalam Azra, 2002: 91). Dalam academic venture, ketidakkeniscayaan sejarah adalah sesuatu yang wajar Selain pemahaman masa lalu dan penyalahgunaan sejarah, kontroversi dalam sejarah juga dapat muncul yang disebabkan persoalan memadai atau tidaknya sumber-sumber dan teknis atau corak sumber-sumber sejarah yang tersedia; pendekatan dalam penafsiran, motif-motif, kecenderungan intelektual pandangan dunia penulis sejarah, dan sebagainya (Gonggong, 1999, dalam Azra, 2002: 92).

Namun demikian, pada dasarnya sejarah dapat sangat berguna untuk membentuk nilai-nilai dalam kehidupan berbangsa dan bernegara. Morris R. Coen (1947: 276 dalam Azra, 2002: 93), filsuf sejarah, mengatakan bahwa memelajari sejarah dan memahami sejarah mungkin tidak dapat menyelesaikan berbagai masalah etis yang dihadapi individu dan masyarakat, tetapi sejarah merupakan prasyarat yang diperlukan untuk memahami masalah tersebut dengan baik. Dari segi ini sejarah memberikan kesempatan kepada manusia untuk memiliki pengetahuan tentang dirinya, tentang masalah-masalah yang dihadapinya; pemahaman tentang sumua ini sangat penting bagi pembentukan nilai-nilai, dan sekaligus untuk menumbuhkan rasa identitas ( sense of identity), baik tingkat individu-personal maupun komunal-nasional.

Banten yang dulu bersinar dalam sejarah Indonesia, sekarang seolah redup tidak bercahaya menarik untuk dijadikan bahan kajian. Pasangsurut Banten oleh kekuasaan yang berganti-ganti telah meninggalkan jejak-jejak yang dapat dijadikan bahan pelajaran. Salah satunya adalah kebijakan penguasa dalam mengatur daerahnya. Fokus utama tulisan sejarah sosial ini membahas penataan daerah oleh para penguasa yang berganti-ganti dan pengaruhnya terhahap masyarakatnya. Paling tidak ada dua topik pembahasan yang saling berkaitan, yaitu: Pertama, kebijakan penguasa dalam mengatur Banten yang multikultur; kedua, pengaruh yang dirasakan masyarakat Banten yang multikulur terhadap kebijakan penguasa. Harapan penulisan artikel ini adalah memberikan sesuatu untuk historiografi Indonesia (umumnya) dan historiografi Banten (khususnya), yang masih belum dijadikan bahan belajar para pengambil kebijakan.

\section{BANTEN SEBAGAI LOKASI ${ }^{1}$}

Satu bagian Indonesia di ujung barat pulau Jawa membentang tanah seluas $9.160,70 \mathrm{~km}^{2}$ yang dibatasi lautan di bagian selatan, utara, barat, dan daratan di bagian timurnya, kaya sumber daya alam yang potensial. Setiap November-Maret musim hujan datang di sini, dengan cuaca yang didominasi angin barat (dari Sumatera Hindia sebelah selatan India); Setiap Juni-Agustus musim kemarau datang di sini, dengan cuaca didominasi oleh angin timur yang menyebabkan sebidang tanah ini di bagian selatannya mengalami kekeringan yang keras. Dataran rendah dengan ketinggian 0-50 $\mathrm{m}$ dpl terdapat di sepanjang pesisir utara, dan sebagian pesisir selatan dengan kemiringan lereng berkisar antara 0-15\%. Topografi perbukitan bergelombang sedang dengan kemiringan lereng $15-25 \%$ terdapat di 
sebagian besar sebidang tanah di Jawa ini, dan topografi perbukitan terjal dengan kemiringan lereng $>25 \%$ terdapat di sebagian kecil bagian selatannya. Di sebagian lainnya, terdapat pegunungan yang relatif sulit untuk diakses, namun menyimpan potensi sumber daya alam. Topografi tersebut, secara umum digunakan manusia yang menghuninya di lingkungan pantai utara untuk sawah irigasi teknis dan setengah teknis, kawasan pemukiman serta industri. Manusia di kawasan bagian tengah memanfaatkannya untuk sawah irigasi terbatas dan kebun campur serta sebagian berupa pemukiman pedesaan. Manusia di bagian barat memanfaatkannya untuk pertanian. Namun di bagian selatan yang merupakan cekungan yang kaya air masih belum dimanfaatkan secara efektif dan produktif oleh manusia penghuninya. Di bagian yang belum dikelola secara optimal ini dikelilingi bukit-bukit bergelombang dengan rona lingkungan kebun campur, talun, dan hutan rakyat yang tidak terlalu produktif. Lahan yang ada masih didominasi untuk sawah, perkebunan dan hutan rakyat. Lahan sawah proporsinya berkisar antara $10 \%$ sampai dengan $>50 \%$; Lahan perkebunan dan hutan rakyat proporsinya berkisar antara 10\% sampai dengan $>50 \%$ (Tim Penyusun, 2003: 1-3). Sebidang Jawa di ujung barat itu kini menjadi wilayah administratif Provinsi Banten.

Pada 1999 membawa angin perubahan besar di Indonesia, termasuk tata daerah: lahirnya regulasi otonomi daerah, dan bertambahnya provinsi dari 27 menjadi 33, dan satu provinsi telah menjadi negara. Perubahan yang terjadi dilatarbelakangi krisis (ekonomi) dan pembangunan yang diterapkan pemerintah Orde Baru, dan kenyataan ini telah banyak kajian yang dilakukan, baik untuk menjelaskan maupun mencari solusinya. Analis pasar memandang krisis sebagai akibat lemahnya perbankkan, spekulasi real-estate, terlalu tingginya penilaian terhadap berbagai mata uang asing, dan ketidakpastian politik (Jackson, 1999:10 dalam Thee, 2004: 113). Kaum ekonom liberal fundamentalis melihat krisis disebabkan oleh lemahnya fundamental ekonomi (ADB, 1999: 24-25 dalam Thee, 2004: 114).
Lemahnya fundamental ekonomi disebabkan oleh faktor domestik (Djiwandono, 2000: 49; Hill, 2000: 122-123 dalam Thee 2004: 114). Sementara itu, Chaniago (2003: 200) menyebutkan ada tujuh ketimpangan yang diwariskan Orde Baru yang semakin memperparah krisis ekonomi: ketimpangan penyebaran aset di kalangan swasta, kesenjangan ekonomi antarsektor, kesenjangan antarwilayah, ketimpangan antarwilayah, kesenjangan antargolongan sosial-ekonomi, kesenjangan pembangunan diri manusia Indonesia, ketimpangan desa-kota.

Salah satu daerah yang menghadapi tujuh kesenjangan dan berusaha mengatur dirinya sendiri itu adalah Banten. ${ }^{2}$ Dengan kesenjangan itu, ekonomi, pendidikan, dan budaya di Banten menjadi terbelakang. Tanggal 3 Oktober 2000 sebidang Jawa di ujung barat itu menjadi hari terakhir bagian Provinsi Jawa Barat. Rabu siang menjelang sore, 13.30, 4 Oktober 2000, bagian barat Jawa itu namanya menjadi Provinsi Banten. Hari pengesahan pemisahan wilayah di Jawa bagian Barat itu kemudian setiap tahun diperingati sebagai hari kelahiran provinsi ke-30 di Republik Indonesia. Dalam euforia reformasi ini, untuk menjadi provinsi prosesnya sangat dinamis: ada kalanya optimis, ada kalanya pesimis. ${ }^{3}$

Banten menjadi salah satu anak emas otonomi daerah. Seiring menjadi provinsi, nilai ekonomis dan komersil Banten menjadi lebih tinggi karena lokasi yang diperbutkan. Di antaranya, harga tanah menjadi lebih mahal. Misalnya, sebelum menjadi provinsi (masih isu) harga tanah daerah Bayah, Malimping, Cikotok naik tiga kali lipat, dari $\mathrm{Rp} 10.000 / \mathrm{m}^{2}$ menjadi $\mathrm{Rp}$ $30.000 / \mathrm{m}^{2}$ (Kompas, 13 September 2000). Sekarang ini, di lokasi yang tidak jauh dari Malimping (Pandeglang), ketika pemerintah akan menjadikan tanah warga untuk pembangunan instalasi PLTU Banten II, tanah warga di Labuan (Pandeglang) dihargai Rp 51.000/m² (Radar Banten, 2,5, 8, 18 Mei 2007). ${ }^{4}$ Tidak aneh, dengan keseksian lokasi ini di berbagai daerah di Banten muncul keinginan untuk memekarkan diri. Contohnya, pemekaran Kabupaten Serang menjadi dua yaitu Kota dan Kabupaten Serang; di 
Pandeglang dua daerah yang ingin memekarkan: Cibaliung dan Caringin; Tangerang: Kecamatan Tangerang Selatan.

Banten memiliki posisi geografis yang sangat strategis. Terletak di ujung bagian Barat pulau Jawa dan berada di pintu Selat Sunda, Banten dapat dikatakan berfungsi sebagai pintu gerbang Barat dari kepulauan Nusantara. Pendudukan Malaka oleh Portugis pada 1511 dapat dikatakan sebagai suatu berkah tersembunyi bagi Banten. Sejak itu, pedagang Muslim mengalihkan jalur pelayarannya melalui pantai barat Sumatera dan tibalah di Banten, maka kemudian Banten berkembang menjadi pelabuhan transito para pedagang Islam dalam pelayaran ke bagian timur Nusantara (Lapian, 2004). Sejak itu, Banten menjadi kota yang didatangi golongangolongan etnis yang berbeda. Dalam hal ini, Banten tidak berbeda dengan kota-kota pelabuhan di Jawa, golongan-golongan yang secara kultural heterogen hidup di dalam kawasannya masingmasing dan di bawah pimpinan mereka sendirisendiri. Di bawah kasultanan Islam, Banten menjadi sebuah tempat berbagai suku dan bangsa hidup berdampingan dengan damai. Masyarakatnya merupakan konglomerasi dari sejumlah komunitas etnik yang memiliki keyakinan yang berbeda-beda, seperti Jawa, Sunda, Arab, Tionghoa, Melayu, dan Eropa. Jejak-jejak multikulturalisme dapat dilihat dari situs-situs sejarah yang masih ada. Di antaranya, Masjid Agung Banten Lama. Masjid yang menjadi tempat wisata ziarah ini diarsiteki seorang Tionghoa bernama Cek Ban Cut, dengan desain atapnya bertumpuk lima yang memperlihatkan idiom pagoda Cina, baik dari bentuk, ekspresi, hingga ukirannya (Setia, 2002). Unsur menara masjid, yang kemudian menjadi pelapor masjid bermenara di Indonesia, diarsiteki oleh seorang Belanda. Menurut Pijper (1947: 280 dalam Setia, 2000) menara berbentuk segi delapan itu mengingatkan pada bentuk mercusuar, khususnya mercusuar Belanda. Ragam hias menara tampak terpengaruh oleh seni ragam hias Jawa, seperti hiasan kepala berbentuk dagoba atau tumpal (hiasan segitiga memanjang). Bukti peninggalan multikultur di
Banten adalah menara mercusuar di Anyer, Benteng Speelwijk, Tembok Keraton, dan Pecinan.

Sebidang Jawa di ujung barat yang kini menjadi provinsi itu kini seolah menghilangkan jejak multikultur masyarakatnya, dan dibawa menuju monokultur. Banten dicitrakan sebagai kota religius (Islam) saja, sehingga simbol-simbol yang mendukungnya sangat ditonjolkan. Bahkan, dalam konteks kebudayaan, kesenian-kesenian yang dimunculkan sangat menonjolkan monokultur (Tim Penyusun Subdin Kebudayaan, 2003). Namun, monolitas yang dibawa menghadapi kebingungan yaitu krisis identitas apa yang asli dari Banten? Wujud lain dari monolitas adalah wacana putra daerah, apalagi menjelang Pilkada. Padahal mencari akar putra daerah sama sulitnya dengan menegakkan benang basah. Isu itu jelas mengusik rasa keadilan banyak pihak. Penjelasan akan persoalan tersebut biasanya mengikuti selera politik dominan.

\section{DARI RAJA MENJADI GUBERNUR: Penataan Daerah Banten dari Zaman Kerajaan sampai Zaman Reformasi}

Banten sebagai objek kajian telah banyak yang menulis, baik tulisan ilmiah maupun tulisan pesanan. $^{5}$ Banyaknya tulisan tentang Banten sangat dimungkinkan karena sumber arsip yang tersedia memang cukup banyak (Utomo, 1997: 126) dan fenomona yang ada memang sangat menarik, apalagi sumber arsip pada era masuknya pedagang Eropa di daerah ini. Misalnya, Arsip VOC (Verenigde Oost-Indische Compagnie) yang berupa Resolution Van Het Casteel Batavia, Daghregister Van Het Casteel Batavia, Corespondentie Buiten Kantoren/Gewestelijke Stukken Bantam. Arsip Pemerintah Inggris di Jawa, Arsip Pemerinrah Hindia-Belanda yang berupa Algemeen Secretarie, Departement Binnenlands Bestuur, Directie Cultures, Gewestelijke Stukken/Residentie Archieven, Residentie Archeiveb "Pasar Ikan, dan Memorie van Overgrave. 
Sejarah Banten adalah sejarah tentang "lahir dan tumbangnya" kekuasaan pribumi lahir, tumbuh, berkembang menjadi pusat dagang, melawan monopoli, perang-kalah, hegemoni asing, dominasi, dan akhirnya kolonialime. Sejak dalam cengkraman kekuasaan Hindia Belanda, Kerajaan Banten, yang pernah disegani di perairan Nusantara, seakan telah menjadi daerah sampingan saja (Abdullah, 2003 dalam Lubis 2003a: xvv). Beberapa tulisan sejarah Banten yang menuliskan "lahir dan tumbangnya" kekuasaan pribumi di antaranya Sedjarah Banten (Roesjani, 1954); Catatan Masa Lalu Banten (Michrob \& Chudori, 1993); Sejarah Banten: Banten dalam Pergumulan Sejarah: Sultan, Ulama, Jawara (Lubis 2003). Sebagai sebuah kerajaan maritim yang pernah disegani di Nusantara, ahli sejarah maritim Indoneisa, menuliskan Banten secara garis besar sebagai berikut (Lapian, 2004).

Sumber sejarah pertama yang menyebut tentang keberadaan Banten adalah laporanlaporan berita Cina. Dalam sebuah laporan berita Cina yang ditulis pada tahun 1430 (Shun Peng Hsiang Sung) nama Banten disebut-sebut sebagai bagian dari beberapa rute pelayaran yang dibuat pada tahun 1421 oleh seorang pelaut Cina yang bernama Mao' K'un. Rute palayaran tersebut ialah; Banten-Timor, Banten-Demak, Banten-Banjarmasin, Kreung (Aceh)-BarusPariaman-Banten. Sumber sejarah lainnya datang dari sorang Portugis, yaitu Tome Pires yang mengunjungi ke Banten sebagai bagian dari lawatannya ke Pasisir Utara pantai Jawa. Lawatan Tome Pires kemungkinan besar terjadi antara tahun 1512-1513. Dalam catatannya, Tome Pires menggambarkan Banten sebagai suatu pelabuhan yang ramai. Banyak perahu jung Cina yang berlabuh di tempat tersebut. Disebutkannya komoditas yang diperdagangkan di Banten adalah beras, bahan makanan, dan lada.

Dari sumber sejarah di atas dapat diperkirakan bahwa sampai dengan tahun 1513 Banten belum merupakan suatu kota pelabuhan Islam. Menurut salah satu sumber sejarah lokal yaitu Sejarah Banten, penyebaran agama Islam di Banten dipelopori oleh Syarif Hidayatullah atau Sunan Gunung Jati. Setelah Sunan Gunung Jati kembali ke Cirebon, kegiatan itu dilanjutkan oleh putranya yang bernama Pangeran Sabakingkin atau Maulana Hasanudin. Dalam upaya menyebarkan agama Islam, Hasanuddin berhasil mengalahkan putra raja Sunda yang bergelar Prabu Pucuk Umum yang keratonnya terdapat di Banten Girang. Sebagai pusat pemerintahan yang baru, Maulana Hasanudin membangun keraton di dekat kuala sungai Banten dan diberi nama Surosowan. Peristiwa tersebut diperkirakan terjadi pada 1526.

Pada awal abad ke-17 Kesulatanan Banten mencapai masa puncak kejayaannya. Masa kejayaan Banten semakin dikukuhkan ketika pada 1638 para penguasa Banten mulai memakai gelar Sultan. Gelar ini merupakan bagian dari persaingan politik antara Banten dan Mataram di Jawa.

VOC sendiri yang dirikan pada tahun 1602 tidak pernah berhasil menerapkan strategi monopoli dagang terhadap Banten. Pelabuhan Banten telah bersifat kosmopolitan, sehingga jika Kompeni memaksakan monopoli bukan hanya Banten yang akan melawan namun juga bangsabangsa Eropa lainnya yang telah memiliki kantor dagang di Banten jauh sebelum kompeni didirikan. Oleh karena itu, kompeni kemudian mengalihkan perhatiannya kepada Jayakarta sebagai alternatif pusat kegiatan perdagangannya di Asia. Keberadaan kompeni di Batavia di kemudian hari terbukti menjadi ancaman yang lebih serius bagi Banten daripada ancaman yang datang dari Mataram.

Kompeni selalu melihat Banten sebagai saingan yang terbesar. Sulit bagi kompeni untuk melakukan monopoli perdagangan rempahrempah, terutama lada, selama Banten masih melakukan politik perdagangan bebas. Untuk menghambat kegiatan perdagangan Banten, kompeni melakukan blokade melalui laut. Banyak perahu jung Cina yang akan berdagang ke Banten dirampas dan orang-orangnya diangkut secara paksa ke Batavia untuk dijadikan 
penduduk. Akibatnya sering terjadi konflik terbuka antara kompeni dengan Banten. Daerah di sekitar Batavia baru benar-benar bisa dikelola oleh kompeni secara baik setelah Sultan Ageng Tirtayasa berhasil dijatuhkan pada 1682 .

\section{Penataan Banten Masa Hindu-Budha}

Walau secara arkeologi Banten sudah ada sejak masa kuarter (pada masa Plestosen atau 1,8 juta tahun yang lalu), yang lahir berbarengan dengan benua Asia (Semah, 1990: 39), namun bukti-bukti penataan daerah pada masa itu belum ditemukan. Pada masa Hindu-Budha, sumber berita Cina (abad ke-5) Banten diceritakan secara ringkas, dan dengan ditemukannya prasasti di Kecamatan Munjul, Pandeglang, tahun 1947 semakin mempertegas bahwa Banten telah ada dan di bawah Kerajaan Tarumanegera (abad ke-7). Pada masa Hindu ini, dengan ditemukannya patung Ganesha, patung Siwa, dan lingga di lereng Gunung Raksa, Pulau Panaitan, Banten masih dijadikan tempat mukim saja, perkampungan, dan masyarakatnya sebagai petani.

Runtuhnya kerajaan Hindu di abad ke-7, muncul kerajaan Sunda (abad ke-8), dan Banten masih menjadi incaran kerajaan adikuasa saat itu. Pusat kekuasaan kerajaan di Banten Girang (pedalaman) yang didirikan pada abad ke-10 (Guillot et.al., 1994: 71). Kerajaan Banten Girang, yang pada awalnya menganggap diri sebagai pewaris Kerajaan Tarum, sepanjang sejarahnya tampil sebagai sebuah negara dagang yang kecil yang berkembang di sekitar Selat Sunda, dan Lampung menjadi bagian dari kerajaan ini. Letaknya yang strategis membuat dua kekuasaan adikuasa saat itu saling berebut: Kerajaan Jawa dan Sriwijaya (Guillot et.al., 1994: 136). Kerajaan ini mengalami masa emas pada abad ke-12 sampai ke13. Selain memiliki keraton (pusat pemerintah), kerajaan Banten Girang juga memiliki pelabuhanpelabuhan. Pengaturan daerah di kerajaan ini masih sangat sederhana, yaitu dibagi menjadi dua: pusat perdagangan dan pusat kekuasan. Tome Pires menggambarkan kondisi Banten sebagai daerah maritim, dan daerah yang ditata sebagai pelabuhan: Banten (Bantam) merupakan kota niaga yang penting setelah pelabuhan Kelapa, yang terletak di tepi sungai, dan kapal jung-jung dapat berlabuh (Cartesao, 1944: 168 dalam Ayatrohaedi, 1997 :1). Lima pelabuhan yang lain: Chiamao (Cimanuk), Xacatra (Jakarta), Caravam, Pondang, (Pontang, Serang), Cheguide (Cikande, Serang), Tamgaram (Tangerang) (Djajadiningrat 1983: 83). Pada awal abad ke-16, kerajaan Banten Girang runtuh, dan digantikan Kesultanan Banten (corak Islam). Perebutan kota Banten ini secara singkat ditulis dalam Sejarah Banten (XVII:34/45 dalam Guillot et.al., 1994: 31). Namun, kepastian angka tahun belum secara jelas disebutkan dalam sumber sejarah lokal itu. Dalam sumber Portugis disebutkan bahwa Banten Girang jatuh ke tangan Muslim pada akhir 1526 atau awal 1527. Walau menjadi medan perang, kondisi kota dan keraton tidak hancur berantakan, dan sampai abad ke-19 masih dimanfaatkan oleh para petinggi/keturunan sultan/bupati Banten (Guillot et.al., 1994: 33).

\section{Penataan Banten Masa Kesultanan}

Banten ditata lebih teratur sebagai sebuah wilayah politis adalah pada masa Kesultanan Banten. Sebagai langkah awalnya, pendiri Kerajaan Islam Banten memindahkan pusat pemerintahan dari pedalaman (Girang) ke Surowowan (pesisir). Faktor geografi, ekonomi, politik sangat berperan dalam pemindahan/pembangunan keraton. Walau Islam mengajarkan tauhid, unsur magis (kosmologis) dalam pemindahan/pembangunan Kesultanan Banten masih sangat kuat. Buktinya, pemindahan dari Girang ke Surowosan atas petunjuk Sunan Gunung Jati (ayah Maulana Hasanuddin, pemegang Kesultanan pertama Banten) juga didasari pada nilai bahwa kerajaan yang runtuh/dikalahkan harus ditinggalkan (Djajadingrat, 1913: 33 dalam Tjandrasasmita, 2000: 52). Sebagai sultan pertama, Hasanuddin berhasil memperluas wilayahnya: Jayakarta, Karawang, Lampung, dan beberapa daerah lain di Sumatra Selatan (Djajadiningrat, 1983: 214).

Pengaturan daerahnya beroreintasi pada

keraton dan pelabuhan: pusat kegiatan dan 
perdagangan. Werthem berpendapat bahwa tata kota-kota Islam dibuat secara tradisional dan direncanakan oleh penguasa tertinggi atas perintah raja. Tata kota Kesultanan Banten dapat dilihat dari denah kota keraton: alun-alun ada di tengah kota, bangunan-bangunan penting didirikan secara tradisional di jalan-jalan lurus berpotongan membentuk bujursangkar (Werthem, 1956:147). Bangunan kompleks keraton dipisahkan dengan bangunan-bangunan lainnya. Bangunan masjid berada di sebelah barat alun-alun, selain sebagai tempat ibadah juga berfungsi sebagai media politik raja. Pasar, tempat kegiatan ekonomi masyarakat, yang berukuran besar di Banten yaitu Karangantu dan Pasar Lama. Pada abad ke-16 ketika orangorang Belanda ke Banten, mereka mempersamakannya dengan Kota Amsterdam, Belanda (Tjandrasasmita, 2000: 38).

Sebagai imbas dari ramainya perdagangan, para pedagang tidak sedikit tinggal di kota Banten. Mereka menempati perkampungan, yang biasanya dihuni secara homogen, di antaranya: kampung India, Pegu dan Siam, Persi, Arab, Turki, dan Cina. Selain kampung-kampung pedagang dari manca, juga ada kampung-kampung dari nusantara: Melayu, Ternate, Banda, Banjar, Bugis, dan Makasar (van Leur 1955:132). Secara fundamental tata kota ini tidak berubah, walau secara politis Kesultanan ada dalam cengkraman VOC.

\section{Penataan Banten Masa Kolonial}

Ketika Kesultanan telah dilumpuhkan VOC, tidak terkecuali penataan daerah, kekuasaan Banten di tangan VOC sampai kebangkrutannya pada 1799. Kongsi dagang yang perkembangannya bertindak laksana negara ini digantikan oleh pemodal utamanya, pemerintah Belanda menguasai sebagian nusantara hampir dua abad (1602-1799), juga Banten. Sebagai penguasa tertinggi di daerah jajahan pertama, Herman Willem Daendels diangkat sebagai Gubernur Jenderal Pemerintah Hindia Belanda.

Banten masih dianggap sebagai daerah yang penting bagi kolonial. Sebagai buktinya,
Daendles membagi bekas wilayah kesultanan menjadi tiga kabupaten. Penamaannya bukan dari nama asal daerah yang secara politis mencerminkan kekuasaan lokal, namun penggantian nama yang baru sangat mencerminkan kepentingan ekonomi-politik, yaitu: Banten Hulu, Banten Hilir, dan Anyer. Sementara itu, penguasa lokal (sisa-sisa Kesultanan) masih ada, namun diperankan sebagai pegawai pemerintah kolonial. Pemerintah Hindia Belanda sebagai legitimator raja, yang secara politis berada di bawah naungan pemerintah pusat di Batavia. Untuk menjamin keloyalan para penguasa lokal ini mereka masih diberikan hak-hak sosial (simbol-simbol keagungan) dan upah (basis konsumsi). Pada 1808 Daendles melantik Sultan Abumufakir Muhammad Aliudin II (sampai 1810), dan menginstrusikan kepada raja agar selalu setia pada pemerintah Hindia Belanda, sebagai imbalannya per tahun ia diberikan gaji 15.000 ringgit (Kartodirdjo, 1984: 112).

Pergolakan politik di Eropa yang berdampak pada negeri-negeri jajahan juga memengaruhi penataan daerah di Banten. Pemerintah Hindia Belanda beralih ke tangan Pemerintah Inggris, 1811-1816. Sebagai penguasa tertinggi, Thomas Stamford Raffles pada awalnya melanjutkan kebijakan yang telah diterapkan Daendles terhadap Kesultanan. Namun, dipicu peristiwa kerusuhan Pangeran Ahmad (putra kedua Sultan Aliudin II) dan kerusuhan oleh Mas Jakaria dan Ngabei Lanang, Raffles menganggap sultan tidak mampu mengatur rakyatnya. Konsekuensinya, status sultan diturunkan menjadi bupati sultan, dan upaya menjadi 10.000 ringgit. Secara kewenangan politis, sultan berada di bawah residen Inggris. Sementara itu, untuk penataan daerah, Raffles membagi Banten menjadi empat kabupaten, yang dipimpin oleh bupati sowan. Keempat kabupaten yang menurut perhitungan Raffles akan lebih memperlancar jalannya pemerintahnya itu dikepalai oleh pemimpin lokal: Kabupaten Banten Lor (Utara) dipimpin Bupati Pangeran Suramenggala, Kabupaten Banten Kulon (Barat) dipimpin Bupati Tubagus Hayudin, Kabupaten Banten Tengah dipimpin Bupati 
Tumenggung Ramlan, dan Kabupaten Banten Kidul dipimpin oleh Bupati Tumenggung Suradilaga (Roesjan, 1954: 43).

Dengan menerapkan sistem pajak di wilayah jajahannya, tidak terkecuali di Banten, Pemerintah Inggris tidak lama menguasai bumi nusantara. Pada 1816 berdasar London Convention 1814 Inggris harus menyerahkan Hindia Belanda kepada pemerintah Belanda. Dalam masa transisi (1816-1819) kekuasaan tertinggi di Batavia dipegang tiga orang komisaris jenderal yaitu Mr.C.Th. Elout, G.G.G.Ph., Baron van der Capellen, dan A.A. Buyskes. Pada 1819 penguasa tertinggi daerah kolonial kembali dipegang oleh Guberur Jenderal. Pengendalian wilayah kolonial oleh van der Capellen daerah Banten diatur dalam dua kabupaten yaitu Banten Utara dan Banten Selatan. Namun penciutan kabupaten di bekas wilayah kesultanan ini berlangsung tidak lama, selanjutnya Banten diatur ke dalam tiga kabupaten lagi, yaitu: Kabupaten Banten Utara dengan ibukota Serang, Kabupaten Banten Selatan dengan ibukota Lebak, dan Kabupaten Banten Barat dengan ibukota Caringin (Roesjan, 1954:43).

Pada1854 pemerintah Hindia Belanda di Batavia mengeluarkan Regeering Reglement yang membagi Banten menjadi empat kabupaten, yaitu: Kabupaten Banten Utara (Serang), Banten Barat (Caringin), Banten Tengah (Pandeglang), dan Banten Selatan (Lebak). Para bupati yang diangkat pemerintahan di Batavia selalu dari kalangan kerabat Kesultanan. Misalnya saja, Raden Adipati Aria Natadiningrat (kakek Hoesein Djajadiningrat, penulis sejarah kritis pertama di Indonesia). Banten dibagi menjadi empat kabupaten berlangsung sampai tahun 1922. Pada 1922 wilayah Keresidenan Banten dibagi menjadi dua afdeling, yaitu Afdeling Banten Utara dan Banten Selatan. Afdeling Banten Selatan ibu kotanya di Rangkasbitung, meliputi dengan Kabupaten Lebak dengan bupati RAA Suradiputra dan Kabupaten Pandeglang dengan bupatinya RTA Karta Adiningrat (Syafrudin, 1993: 309-310). Afdeling Banten Selatan meliputi Kabupaten Banten Utara saja yang beribukota Serang dengan bupati P.A.A. Achmad Jayadingrat.

Menjelang berakhirnya kekuasaan Pemerintah Kolonial Hindia Belanda di tanah air, Jawa dibagi menjadi tiga provinsi, yaitu Jawa Barat, Jawa Tengah, Jawa Timur, dan Banten masuk wilayah Provinsi Jawa Barat (Province West-Java) pada 1 Januari 1926. Di bawah Province West-Java ini keresidenan Banten menjadi Afdeling Banten (satu dari sembilan afdeling di Jawa Barat), yang beribu kota di Serang. Afdeling Banten ini meliputi Kabupaten Serang dengan bupatinya RTA Prawirakusumah, Kabupaten Pandeglang dengan bupatinya RT. Gondosaputra, dan Kabupaten Lebak dengan bupatinya R.A.A. Karta Adiningrat (Syafrudin, 1993: 217).

\section{Penataan Banten Masa Pendudukan Jepang}

Perang Asia Pasifik menghantar perubahan di negeri Hindia Belanda, yang menghantarkan beralihnya kekuasaan ke tangan pendudukan Jepang. Politik perang Jepang mempunyai dua tujuan. Pertama, eksternal, Jepang menekankan 'pembebasan rakyat Asia', guna memperoleh legitimasi operasi-operasinya di negeri asing, dan dukungan dari kaum nasionalis. Kedua, internal, kampanye 'pembebasan Asia' untuk meyakinkan rakyatnya dalam memperpanjang perang dengan Cina. 'Kemakmuran Asia Timur Raya' berkembang menjadi alat untuk merangsang rakyatnya agar berjuang dan memikul berat beban perang (Nakamura, 1988: 3).

Pada 1 Maret 1942 pasukan Jepang menyerbu Jawa. Tentara Belanda memberikan perlawanan yang tidak sepenuhnya, sehingga kalah dalam waktu seminggu, pada 8 Maret 1942. Bendera Jepang berkibar di mana-mana sebagai tanda babakan baru penjajahan di Indonesia. Bulan-bulan pertama mereka disambut suka-cita oleh masyarakat pribumi di kampung. "Asem tenan, wektu iku aku karo bocah-bocah liyane, lungo nang Manggistan karo ngibar-ngibarke gendero puteh," kesal Tohir (75 th) (wawancara Tohir, 2 Mei 2005). (Sial, waktu itu saya dan anakanak yang lain pergi ke Manggistan [nama sebuah 
kampung di Semarang] sambil mengibarkan bendera putih). Secara umum, kedatangan Jepang diterima rakyat dengan penuh semangat pada awalnya. Rakyat pribumi percaya bahwa Jepang datang untuk memerdekakan. Rakyat diperbolehkan mengibarkan bendera merah putih, serta melantunkan lagu Indonesia Raya. Kaum terpelajar sangat menerima kedatangan tentara Jepang, karena mereka memiliki status yang lebih meningkat (Kahin, 1995: 130).

Di awal pendudukan, Jepang bersikap lunak karena memunyai tujuan menduduki Jawa sebagai 'kelahiran kembali Jepang' di selatan, negeri leluhurnya. Jepang menganggap, keterbelakangan yang terjadi di Hindia Belanda karena politik pembodohan yang dilakukan pemerintah kolonial. Untuk itu, Jepang akan membangkitkan potensi masyarakat yang terbelakang ini: Jepang menciptakan suasana pendudukan sebagai sebuah reuni keluarga yang telah lama berpisah. Terciptalah suasana reuni keluarga ini. Contohnya, Letnan Jenderal Imamura sebagai panglima tentara ke-16 menolak kebijakan pendudukan yang keras seperti yang diusulkan Singapura dan Tokyo. Imamura meminta maaf kepada Soekarno yang dipukul oleh seorang tentara Jepang, begitu juga tentara yang memukul Soekarno (Nakamura, 1988:13-19).

Dikuasai Jepang, Keresidenan Banten namanya menjadi Banten Syu, di bawah Jawa Barat, yang terdiri atas tiga ken (kabupaten), yaitu: Serang bupatinya RAA Hilman Jayadiningrat (1935-1945), Pandeglang bupatinya R.T. Jumhana Wiriaatmadja (1941-1945), dan Lebak bupatinya R.T. Hardiwinangun (1944-1945). Sebagai gubernurnya Kolonel K. Matsui, dan R. Pandu Suryaningrat sebagai wakilnya, yang dilantik pada 29 April 1942. Pada 5 Agustus 1942 pemerintah militer Jepang mengeluarkan regulasi yang menyangkut tata daerah di wilayah pendudukannya di Indonesia, UU No.27 dan 28. Isi dari Undang-undang itu yaitu: Jawa dibagi menjadi 17 daerah keresidenan (Syu), dan di bawahnya ada kotamadya (si)/kabupaten (ken). Pemegang kekuasaan syu dipegang oleh orang Jepang (syucokan), dan si dikepalai sico/ken dikepalai kenco. Ken membawahi kawedanan (gun), yang dikepalai wedana (gunco). Gun membawahi son (kecamatan), yang dikepalai sonco (camat), dan son membawahi $k u$ (kelurahan), yang dikepalai kuco (lurah). Pengaturan daerah terkecil adalah tonarigumi (kerukunan warga) (Kurosawa, 1993:47).

Secara tidak langsung pemerintahan militer ini menghapus sistem hukum yang ditinggalkan pemerintah Hindia Belanda. Padahal, walau secara perlahan, hukum moderen ala Barat di Hindia Belanda telah menampakkan corak desentralisasi yang jelas. Demi keefektifan penguasaan atas daerah yang dikuasainya, memudahkan dan melancarkan berbagai sumber daya yang dibutuhkan regulasi zaman kolonial banyak diubah. Pada tahun pertama pendudukan, perubahan difokuskan pada pemantapan pemerintahan sentralistik dan hierarkis di Jawa, hingga terkesan administratif Jawa-sentris. Oendang-oendang No. 28 tentang Pemerintahan Syuu (7-8-2602) mengakhiri asas pemerintahan desentralisasi kolonial Hindia Belanda. Tidak hanya mengganti administrasi pemerintahan, militer-bestuur Jepang juga mengubah simbolsimbol Barat di Indonesia. Dengan Oendangoendang No. 30 tentang Mengoebah Nama Negeri dan Nama Daerah (1-8-2602). Misalnya, nama Batavia dikembalikan menjadi Djakarta, Fort de Kock menjadi Boekitinggi (Wignjosoebroto, 2004: 76 dalam Sastro, 2005: 134).

Di tingkat kampung, regulasi yang menentukan perubahan adalah ditetapkan pemerintah militer Jepang Oendang-oendang No 27 tentang Peroebahan Pemerintahan Daerah (58-2606). Pemerintah pendudukan Jepang membentuk tonarigumi (rukun tetangga) dan aza (rukun kampung). Lembaga kontrol perkampungan ini juga berfungsi sebagai pengerahan tenaga-tenaga kerja paksa (romusha). Tonarigumi, atau rukun tetangga, secara resmi diperkenalkan di Jawa pada Januari 1944. Tonarigumi terdiri atas 10 sampai 20 rumah tangga, yang berfungsi sebagai alat memperkuat cengkeraman pemerintah atas penduduk dan untuk meningkatkan komunikasi dengan mereka. 
Pengumuman resmi tentang pembentukannya dikeluarkan pemerintah militer pada 11 Januari 1944, saat berlangsungnya Konferensi Residen Seluruh Jawa, yang kemudian disusul dengan asasasas untuk menyempurnakan susunan rukun tetangga. Sebelum diumumkan, pemerintah telah mempersiapkan desa percontohan di Kabupaten Jatinegara, Jakarta, dan peserta konferensi dipersilahkan melihat langsung desa tersebut. Tonarigumi yang sangat efektif dalam melakukan kontrol penduduk di Jepang dipraktikan di daerah pendudukan Jepang di Asia (Kurosawa, 1993: 197-198 dalam Sastro, 2005: 136).

\section{Penataan Banten Masa Republik Indonesia}

Proklamasi 17 Agustus 1945 tidak dapat langsung membentuk negara Indonesia ke arah kepenataan yang rapi. Namun, boleh dikatakan, para pendiri bangsa ini telah bekerja sangat cepat. Dua hari setelah kemerdekaan itu, 19 Agustus 1945, pemerintah Republik Indonesia di Jakarta berhasil menetapkan 12 kementerian (Soeara Merdeka, 9 Oktober 1945). Di hari yang sama PPKI (Panitia Persiapan Kemerdekaan Indonesia) membentuk delapan provinsi yang dikepalai seorang gubernur, yang terdiri atas keresidenan yang dikepalai seorang residen. Kedelapan provinsi itu adalah: Jawa Barat, Jawa Tengah, Jawa Timur, Sumatra, Borneo, Sulawesi, Maluki dan Sunda Kecil.

Guna melaksanakan amanat Undang Undang Dasar (UUD) 1945 Pasal 18, dan Aturan Peralihan UUD RI pasal 1 dan 2, serta PP No.2 Tahun 1945, pemerintah membentuk keresidenan yang terdiri atas kabupaten/kotapraja. Banten termasuk keresidenan Provinsi Jawa Barat, dengan residen R. NG. Tirtasoejatna. Keresidenan Banten meliputi tiga kabupaten: Serang, Lebak, dan Pandeglang. Penataan daerah pada awal republik ini secara umum sama dengan penataan pada masa akhir pemerintahan Hindia Belanda. Tidak terkecuali para pemegang jabatan di atas, biasanya diambil dari orang yang menjadi pejabat sebelumnya. Bupati Serang pada awal kemerdekaan: R. Hilman Jayadiningrat, bupati Lebak KH. Tb. Hasan, dan KH. Tb. Abdul Halim sebagai bupati Pandeglang (Lubis ed., 2003b: 207208).

Belanda masih belum mengakui kemerdekaan RI sampai pada 1949. Melalui jalur diplomasi di sebuah meja bundar, titik temu antarnegara penjajah dan negara dijajah itu dapat terwujud pada 17 Desember 1949. Salah satu hasilnya adalah RIS (Republik Indonesia Serikat), dan Banten masuk dalam negara Pasundan. Pada April 1950 muncul kesepatakan bahwa semua bekas negara RIS berbagung dalam Republik Indonesia lagi. Peristiwa ini menjadi titik awal untuk terbentuknya Provinsi Jawa Barat, yang membawahi Banten, berdasar pada UU No. 11 tahun 1950. Dengan regulasi ini, sebuah provinsi dapat mengatur dan mengurus rumah tangganya sendiri, seperti diatur dalam UU No. 22 Tahun 1948 tentang Pemerintah Daerah. Provinsi Jawa Barat meliputi lima keresidenan, yaitu Jakarta, Bogor, Banten, Priangan, dan Cirebon. Untuk mengatur daerah lebih lanjut, pemerintah mengeluarkan UU No. 14 yang menetapkan Tangerang, Serang, Pandeglang, dan Lebak merupakan bagian provinsi Jawa Barat, di samping Bekasi, Kerawang, Purwakarta, Bogor, Sukabumi, Cianjur, Bandung, Sumedang, Garut, Tasikmalaya, Ciamis, Cirebon, Kuningan, Indramayu dan Majalengka (Lubis, 2003a: 185).

Dinamika politik nasional pada 19501960-an telah memengaruhi dinamika tata daerah di Banten pula, muncul keinginan dari elite masyarakat untuk menjadi provinsi tersendiri. Pada 1953, seiring ditetapkannya Aceh dan Yogyakarta menjadi provinsi dengan daerah khususnya, elite masyarakat menghendaki Banten juga sebagai provinsi, mengingat Banten juga memiliki basis sejarah untuk dijadikan daerah istimewa (Michrob \& Chudori, 1993: 284). Keinginan masyarakat Banten ini tidak mendapat tanggapan serius dari pemerintah Jakarta atau pun Jawa Barat. Sepuluh tahun kemudian, pada 1963, dalam sebuah acara di Serang dibentuk Panitia Pembentukan Provinsi Banten (PBB), yang terdiri atas unsur-unsur partai. Setahun umur panitia ini lahir, pada 1964 mereka menemui Menteri Dalam Negeri (Mendagri) di Jakarta. Dengan sikap halus 
dan tegas, Mendagri menolak usulan pembentukan provinsi untuk Banten, dan pemerintah pusat menjanjikan memberikan sesuatu buat Banten. Alasannya, selain Banten telah berjasa dalam masa revolusi, saat itu, pemerintah pusat sedang menunggu kesepakatan Daerah Khusus Ibukota (DKI), yang memungkinkan akan memekarkan wilayahnya sampai ke Tangerang (Mansur, 2001: 88). Pada masa pemerintahan Orde Baru, upaya-upaya untuk mewujudkan Banten sebagai sebuah provinsi terus digerakkan (Lubis, 2003a: 194198), namun tidak berhasil.

Krisis ekonomi Indonesia pada 1997 berbarengan dengan krisis di berbagai negara di Asia Timur penganut teori pembangunan sangat mengguncang dunia. Krisis ini terjadi pada saat pertumbuhan ekonomi mencapai angka tercepat di dunia, dan merupakan krisis tercepat. Krisis ekonomi ini kemudian menghantarkan penguasa otorieter Soeharto lengser, dan periode perjalanan bangsa ini memasuki era reformasi (Sastro \& Tandiono, 2004: 2). Dalam geliat reformasi ini muncul lagi semangat masyarakat Banten untuk mandiri, menuntut status menjadi provinsi di era desentralisasi. Bagai seorang pengembara yang sudah memahami jalan tujuannya, masyarakat Banten dengan lancar dan teratur rapi dapat meraih cita-citanya hidup dalam naungan provinsi tersendiri.

Provinsi ke-30 di Republik Indonesia ini terdiri atas empat kabupaten (Lebak, Pandeglang, Serang, dan Tangerang) dan dua kota (Cilegon dan Tangerang). Di tahun-tahun awal menjadi provinsi, muncul gejolak dari pemerintah daerah tingkat kecamatan dan desa untuk memekarkan diri. Pemekaran tahun 2001-2002 sebanyak enam kecamatan; sejak 2002-2003 terdapat sebanyak dua kecamatan; tahun 2003-2004 sebanyak delapan kecamatan; tahun 2004-2005 sebanyak tiga kecamatan. Jadi, selama kurang lebih lima tahun terdapat 18 wilayah kecamatan. Tabel 1 menunjukkan perkembangan penataan daerah Provinsi Banten.

Setelah menjadi provinsi, Banten masih menghadapi banyak tantangan, terutama dalam mewujudkan cita-cita masyarakat yang maju dan sejahtera. Bahkan, ditinjau dari prioritas pembangunan Banten terbagi menjadi dua wilayah: utara dan selatan. Wilayah Banten utara meliputi Kota Tangerang, Kabupaten Tangerang, Kabupaten Serang, dan Kota Cilegon, luasnya 3.193,97 $\mathrm{km}^{2}$, dihuni oleh sekitar enam juta penduduk. Wilayah selatan meliputi Kabupaten Lebak dan Kabupaten Pandeglang dengan luas $5.606,86 \mathrm{~km}^{2}$. Sesuai dengan kebijakan pemerintah daerah yang menetapkan wilayah utara sebagai kawasan industri, kegiatan ekonominya didominasi industri, perdagangan, dan jasa. Wilayah selatan adalah daerah pertanian, pertambangan, perkebunan, dan pariwisata (https://www.bantenprov.go.id/, diakses pada 24 Juni 2007). ${ }^{6}$

Tabel 1. Jumlah Kecamatan, Kelurahan, dan Desa di Provinsi Banten pada 2005.

\begin{tabular}{lrrr}
\hline Kabupaten/kota & Kecamatan & Kelurahan & Desa \\
\hline Kab. Pandeglang & 31 & 13 & 322 \\
Kab. Lebak & 23 & 5 & 295 \\
Kab. Tangerang & 26 & - & 328 \\
Kab. Serang & 34 & 22 & 351 \\
Kota Tangerang & 13 & 104 & - \\
Kota Cilegon & 8 & 2 & 41 \\
\hline Jumlah & 135 & 146 & 1337 \\
2004 & 132 & 146 & 1337 \\
2003 & 124 & 144 & 1337 \\
2002 & 122 & 144 & 1337 \\
2001 & 116 & 146 & 1330 \\
\hline \multicolumn{1}{c}{ Sumb }
\end{tabular}

Sumber: Badan Pusat Statistik, 2005:17.

Hasilnya, pembangunan di Banten seolah menghasilkan dua daerah yang berbeda pula: utara dan selatan. Jika Banten utara tampak gemerlap, Banten selatan sebaliknya. Kemiskinan dan ketertinggalan tercium dari desa-desa di Kecamatan Cimaraga, Muncang, Cipanas, Cikulur, Bojongmanik di Kabupaten Lebak. Kondisi yang hampir sama dijumpai di desa-desa di Kecamatan Angsana, Pagelaran, Cigelulis, Cikeusik, dan Panimbang di Kabupaten Lebak. Pada kedua kabupaten ini perkembangan wilayah terhambat 
oleh kondisi alam. Kawasan sekitar Gunung Halimun-Kendeng hingga Malingping, Leuwidamar hingga Bayah berupa pegunungan yang relatif sulit dijangkau. PDRB Kabupaten Lebak pada 2005 hanya $R p$ 3,28 triliun (5,36 persen) dan Kabupaten Pandeglang cuma Rp 3,36 triliun (5,48 persen).

\section{DARI MONOKULUR KE MULTIKULTUR, KEMBALI MONOKULTUR (?) ${ }^{7}$ Pengaruh Penataan Daerah Banten terhadap Kehidupan Masyarakat}

Tata daerah erat hubungannya dengan masyarakat dan ekologi. Banten yang diperkirakan pada zaman plestosen ( 1,8 juta tahun yang lalu) sudah dihuni manusia mulai dijadikan sebagai daerah (bagian dari kekuasaan politik) sejak adanya kerajaan Hindu, Tarumanegara (abad ke-5). Diperkirakan pada abad ke-10 pelabuhan di daerah ini sudah ada, dan mulai intens kedatangan pedagang dari luar negeri (Cina dan Eropa) pada abad ke-14. Kedatangan para pedagang dari berbagai negeri menjadikan Banten sebagai daerah multietnis yang memunyai kultur yang beragam. Di bawah Kesultanan Banten, perdagangan lada membuat Banten menjadi kota pelabuhan yang penting. Kapal-kapal dagang Cina, India dan Eropa singgah dan berdagang di Banten. Dalam melaksanakan perdagangan, Banten menerapkan sistem perdagangan terbuka. Artinya, semua pedagang dari berbagai bangsa dibebaskan untuk berdagang di Banten.

Sebagai sarana yang mempertemukan berbagai bangsa di pelabuhan Banten adalah pasar. Salah satu di antara pasar tersebut adalah pasar Karangantu yang terletak pada sebuah tanah lapang yang ada di bagian timur kota. Pasar ini buka dari pagi hingga siang hari. Di pasar tersebut dapat ditemukan para pedagang dari berbagai bangsa seperti Bugis, Jawa, Melayu, Portugis, Arab, Turki, Cina, Keling, Pegu, Bengali, Gujarat, Malabar, dan Abesenia. Pasar kedua terletak di daerah Paseban dan buka sepanjang hari. Sementara itu, pasar yang ketiga terletak di daerah Pacinan. Pasar ini buka sehari sebelum atau sesudah pasar-pasar lainnya. Mengenai barang yang diperdagangkan antara lain adalah; lada, cengkeh, pala, buah-buahan, kacang-kacangan, gula, madu, berbagai jenis manisan dan bahkan juga keris, tombak, pisau, dan berbagai jenis senjata lainnya.

Semaraknya kegiatan perdagangan di Banten telah menarik kedatangan para penduduk dari berbagai suku bangsa untuk menetap di sana seperti orang-orang Jawa, Makassar, Melayu, Bengal, Arab, Gujarat, dan sebagainya. Bahkan, orang-orang Eropa juga turut bermukim dan membuka kantor dagang di Banten. Di kota pelabuhan tersebut terdapat kantor dagang milik orang Portugis, Perancis, Denmark, Inggris, dan kantor dagang milik orang Belanda. Dari keanekaragaman para pedagang yang berdagang di Banten terlihat bahwa Banten memiliki jaringan perdagangan yang sangat luas. Hampir semua bangsa yang melakukan perdagangan internasional di masa kejayaan Banten dapat ditemukan di kota pelabuhan tersebut. Untuk mengatur kegiatan perdagangan di pelabuhan, Sultan Banten mengangkat seorang pejabat yang disebut dengan syahbandar. Jabatan ini memiliki arti yang sangat penting, karena syahbandar adalah orang yang berwenang untuk memberi izin bagi kapal-kapal yang akan berlabuh dan berdagang di pelabuhan. Oleh karena itu, syahbandar biasanya dijabat oleh seorang kepercayaan Sultan. Seorang syahbandar yang paling berhasil dalam sejarah Banten adalah seorang Cina kepercayaan Sultan Ageng Tirtayasa yang bernama Kaytsu (Lapian, 2004).

Sejak pembukaan pelabuhan, apalagi di bawah kesultanan Islam yang menerapkan politik pelabuhan terbuka, dapat dikatakan Banten masyarakatnya multietnis dan multikultur. Moh. Ali Fadillah memeriodesasi perkembangan masyarakat Banten sebagai berikut.

\section{Masyarakat Petani}

Di Banten sebelum abad ke-10, sebagai masyarakat awal, dalam berproduksi sektor petanian yang sederhana telah dipraktikkan, dengan sistem 
huma. Struktur masyarakat masih sederhana, egaliter, dan mengutamakan gotong-royong. Kepemimipinan dalam organisasi sosialnya berdasar pada kharismatik, yang ditentukan oleh pengetahuan, ahli mistik, dan pertanian. Budaya masyarakatnya masih heterogen. Agama yang dianut adalah agama asli masyarakat, animisme. Untuk melihat stereotipe masyarakat Banten yang monokulutur, dengan pertanian sistem huma, sekarang ini kita dapat melihatnya pada masyarakat petani di Kenekes, Pandeglang. (Yudhistira, 1997, dalam Ali 2001:75). Dalam masyarakat yang monokultural ini, penataan daerah belum ada. Masyarakat masih dalam organisasi sosial yang sederana, ikatan desa.

Mengenai penduduk yang berdiam di kepulauan nusantara, beberapa teori mengatakan terjadinya gelombang perpindahan penduduk (the waves of migration). Begitu pula dari mitos dan cerita rakyat banyak dijumpai kisah orang (dalam) perjalanan. Ada yang menetap dan kemudian dianggap sebagai "pahlawan budaya" (culture hero), peletak kehidupan sosial-politik masyarakat setempat. Kisah negeri atau pulau tenggelam dan orang terdampar memenuhi halaman ceritera rakyat di kepulauan (Lapian, 1992). Dalam konteks seperti itulah keberpencaran penduduk merupakan hal wajar. Suatu teori terbaru tentang asal-usul manusia yang mendiami Tanah-Air ini bukan berasal dari Cina atau India belakang, tetapi dari wilayah itu sendiri, yang kemudian dikenal sebagai rumpun besar Austronesia. Seorang dokter bernama Stephen Oppenheimer menulis pengalamannya selama bekerja sebagai tenaga medis di Thailand, Malaysia, Indonesia sampai pada pendapat di atas. Metode yang digunakan adalah dengan mengumpulkan cerita setempat mengenai banjir. Menurut pendapatnya, mitos banjir itu terdapat di seluruh masyarakat kepulauan ini. Ketika itulah penduduk di pantai memencar dan berpindah ke pulau-pulau lain (Oppenheimer, 2001).

\section{Masyarakat Urban Transisional}

Tatkala mendapat desakan dari bangsa Tionghoa dan Hindu, masyarakat Banten yang telah berperadaban pertanian yang masih sederhana mulai melirik dunia laut. Hawa yang subur, dan sedikitnya penduduk menjadikan masyarakat petani yang senang hidupnya itu, tinggal diam dan menerima, sedangkan kepulauan luas yang sangat banyak itu belum dioptimalkan, namun malah menarik hati masyarakat luar. Dapat dikatakan, sesudah ada pengaruh Hindu, kebudayaan masyarakat Banten bertambah naik dan mereka mulai berkenalan dengan perdagangan. Agama animisme terdesak oleh agama Hindu dan Budha. Budaya yang lebih pintar itu mengajarkan pemerintahan negeri, yang menuju teknik kebudayaan yang lebih sempurna. Penduduk Pulau Jawa yang suka damai itu belum memiliki sikap pertentangan kelas dalam arti yang seluasluasnya terhadap agama baru tersebut. Mereka tidak memberi kesempatan kepada pengikutpengikut agama Hindu untuk mempertaruhkan kepercayaan mereka dalam sebuah pertentangan, yakni Hinduisme yang aristokratis dan Budhisme yang lebih demokratis (Tan Malaka, 1926/2000). Pertentangan agama, oleh masyarakat Jawa yang tidak mengenal kelas itu, dapat diredam. Sedikit atau banyak, semua filsafat Hindu diterima oleh penduduk.

Dalam perkembangan masyarakat yang telah bercampur dengan budaya dari luar, Hindu/Budha, Banten yang telah mengenal sistem pertanian padi sawah (Ali, 2001:75), juga mulai mengembangkan pelabuhan sebagai tempat interaksi ekonomi maupun budaya lintas etnis, Cina, Arab, dan India. Raja sebagai pusat kekuasaan belum memprioritaskan agenda penataan daerah. Penguasa memisahkan antara pusat kekuasaan dengan pusat perekonomian. Dalam hal ini, pusat kekuasaan terdiri dari masyarakat monokulur, sedangkan pusat ekonomi terdiri atas masyarakat yang multikultur.

\section{Masyarakat Menuju ke Arah Kosmopolitan yang Multikultur}

Para pedagang Islam yang datang di Banten juga mendiseminasikan agamanya kepada masyarakat setempat. Puncaknya melahirkan kekuatan politis, berdirinya kesultanan. Masuknya Islam di Banten 
boleh dianggap sebagai pembaharu masyarakat. Di bidang perdagangan dengan dikuasainya Pelabuhan Malaka ke tangan Portugis telah membawa kesempatan Pelabuhan Banten mengambil peran sebagai jalur perdagangan internasional. Sebagai penunjang bagi keberhasilan dari kegiatan perdagangan internasional, Banten juga menjalin hubungan diplomatik dengan berbagai bangsa, termasuk pedagang dari Eropa. Pada 1681 tercatat bahwa Banten memiliki seorang duta besar yang ditempatkan di kota London, Inggris. Keberadaan duta besar Banten di Inggris itu mencerminkan bahwa Kesultanan Banten pada abad ke-17 mendapat pengakuan internasional dan dipandang sejajar dengan negara-negara besar berdaulat lainnya.

Pada 1596 di Banten tiba sebuah armada dagang Belanda di bawah pimpinan Cornelis de Houtman. Tujuan kedatangan armada Belanda adalah untuk menyelidiki kemungkinan untuk melakukan perdagangan rempah-rempah di Nusantara. Kedatatangan mereka di Banten untuk pertama disambut dengan hangat. Akan tetapi dalam perkembangannya, mereka mulai melakukan berbagai kecurangan dan berbagai tindak kekerasan yang mengakibatkan munculnya sikap permusuhan dari orang-orang Banten. Hubungan yang memburuk ini dicoba untuk diperbaiki oleh armada dagang Belanda lainnya di bawah pimpinan Van Neck yang datang ke Banten dua tahun kemudian. Upaya Van Neck dalam mengambil hati penguasa Banten berhasil. Sejak itu orang-orang Belanda dizinkan untuk membuka kantor dagang di Banten (Lapian, 2004).

Adanya para pedagang dari Eropa menjadikan etnis di Banten semakin beragam. Di sini, terjadi interaksi yang saling pengaruhmemengaruhi, relasi yang ada di antara etnis yang beragam itu damai tanpa ada konflik. Hal ini tidak lepas dari peran penguasa yang menata daerah, dengan memberikan tempat-tempat tinggal kepada masing-masing etnis secara bebas. Fragmentasi relasi masyarakat sangat dipengaruhi oleh perdagangan di antara mereka.

\section{Multikultur dalam Represitas Penguasa}

VOC yang berdiri pada 1602 saat pelabuhan Banten telah bersifat kosmopolitan. Pada 1682 setelah Sultan Ageng Tirtayasa berhasil dijatuhkan, Batavia benar-benar dikuasai Kompeni. Dengan dikuasainya Batavia secara total oleh VOC telah menjadikan kongsi dagang ini dapat memonopoli pelabuhan Sunda Kelapa, dan Banten dianggap sebagai saingan yang potensial. Upaya-upaya untuk menguasai Banten terus dilakukan, dan puncaknya pada 1808 , dengan dihancurkannya Kesultanan oleh Daendles. Hal ini menjadikan Banten bagian dari Batavia, ibukota pemerintah Hindia Belanda. Tidak hanya ekonomi, namun politik dan masyarakat juga dikuasai pemerintah kolonial. Beberapa kebijakan yang mengubah struktur masyarakat Banten di antaranya menjadikan bangsawan sebagai bagian birokrasi, dan pengaturan tempat tinggal berdasar etnis.

\section{SIMPULAN}

\section{Bukan Dekolonialisasi tetapi Rekolonialisasi}

Sejak Kesultanan Banten dihancurkan oleh kolonial, daerah ini menjadi wilayah yang berpusat di Batavia. Banten hanya berfungsi sebagai daerah pendukung pemerintah pusat dan menjadi daerah pelengkap. Reformasi melahirkan Banten sebagai provinsi baru, harapan besar dipancangkan di atas status baru ini. Namun, ini semua seperti mimpi di siang bolong bagi rakyat Banten. Kepemimpinan di tingkat provinsi yang telah berlangsung selama dua periode, tampak tidak jauh berbeda dengan masa reformasi, Banten masih belum maju dan sejahtera. Masyarakat masih belum menjadi prioritas setiap kebijakaannya.

Namun demikian, penataan daerah di Banten dalam lintas orde ini telah menunjukkan kepada kita bahwa masalah penataan daerah tidak semata-mata hanya urusan pemekaran. Dalam beberapa periode daerah Banten telah memperlihatkan, demi kepentingan penguasa, daerah dan masyarakat telah ditata, yaitu adanya pemekaran dan pengerutan. Proses pembentukan bangsa Indonesia dari ikatan-ikatan kekuasaan kecil dalam sebuah negara adalah suatu proses 
sejarah, begitu juga proses Banten menjadi provinsi. Memelajari sejarah lokal suatu daerah memunyai manfaat, di antaranya mengetahui solidaritas untuk melahirkan cita-cita yang diinginkannya. Solidaritas sebuah bangsa biasanya lahir dalam suasana senasib-sepenanggungan. Dalam sejarah ada pengalaman yang dihadapi, dihayati, atau diderita bersama-sama, tetapi dalam lain sejarah masing-masing daerah, suku atau kelompok telah menempuh perjalanan yang berbeda. Seperti sebuah keluarga, masing-masing memiliki kisah yang beragam, dan untuk dapat menghayati bersama, penuturan kisah sangat penting. Untuk itu, mengenal dan mengerti jalan sejarah yang dilewati daerah tertentu juga penting, untuk pemahaman bersama. Mengenal sejarah lokal suatu daerah berarti mengenal sejarah dari sesama bangsa dan ini akan memperluas pandangan kita tentang Indonesia yang multikultur.

\section{CATATAN}

${ }^{1}$ Menurut Chaniago (2003: 200) lokasi adalah mesin pertumbuhan: salah satu aset publik yang paling sering mengalami proses ekonomisasi dan komersialisasi dalam pembangunan.

${ }^{2}$ Banten meliputi Keresidenan Banten dan sejumlah kawedanan, yaitu: Pandeglang, Malimping, Rangkasbitung, Lebak, Cilegon, Serang, dan Tangerang. Sekarang secara administratif Provinsi Banten mencakup empat kabupaten (Serang, Pandeglang, Lebak, Tangerang) dan dua kota (Tangerang dan Cilegon).

${ }^{3} \mathrm{Hal}$ ini dapat dilihat dari berita-berita di media massa, lokal maupun nasional, dalam meliput proses Banten menjadi provinsi. Misalnya saja judul-judul di Harian Kompas: "Banten Menggeliat" (5 Juli 1999), "Tentang Pembentukan Provinsi Banten Pemerintah takkan Halangi Keinginan Masyarakat” (2 Agustus 1999), "Provinsi Banten Belum Bisa Diwujudkan" (7 Agustus 1999), ”DPR akan Ajukan RUU Provinsi Banten" (26 Januari 2000), "Beragam Pendapat Warga Soal Provinsi Banten" (27 Januari 2000), "Pembentukan Provinsi Banten: Niat Baik Jangan Jadi Bumerang" (3 Februari 2000), "Pembentukan Provinsi Banten Tak Perlu Persetujuan DPRD Jabar" (4 Februari 2000), "Keinginan Membentuk Provinsi Banten Menunggu
Tendangan Bola DPR" (9 Februari 2000), "Bila Keran Kebebasan Dibuka Terbentuk 100 Provinsi (11 Februari 2000), "Gambaran Pesimis untuk Wujudkan Provinsi Banten (21 Februari 2000), "Soal RUU Inisiatif Provinsi Baru: Jangan Terburu-buru Bentuk Provinsi (22 Februari 2000), "Gubernur Jabar Dukung Pembentukan Provinsi Baru (23 Februari 2000), "Mendesak, Kajian Kritis Potensi Banten" (3 Maret 2000), "Pansus DPR Mulai Bahas RUU Banten (9 Maret 2000), "Banten Dipastikan Lepas dari Jabar (21 Maret 2000), "Jabar Kemungkinan Menjadi Provinsi Priangan” (27 Maret 2000), ”DPRD Jabar Setuju Banten Dilepas" (7 April 2000).

${ }^{4}$ Dalam praktiknya, tanah warga dibeli dengan harga Rp7.000-Rp 15.000/m oleh para calo tanah. Sehingga, sampai sekarang warga melakukan protes atas ketidaktransparanan informasi dan intimidasi dalam proses jual beli tanah (Wawancara dengan KH. Encep Badruzzaman Raffly, tokoh masyarakat Pandeglang, tanggal 20 Mei 2007).

5 Tiga buah tulisan ilmiah (disertasi) yang sangat berpengaruh dalam historiografi Indonesia, yaitu Hosein Djajadiningrat (1913) Chritische Beschouwing van de Sedjarah Banten: Bijdragen ter Kenstcheteing van de Javanaasche Geschiedshrijving. DK Baset (1965) The Factory of The English East India Company in Banten 1602-1682, dan Sartono Kartodirdjo Peasant Revolt of Banten in 1888; It Condition, Course, and Sequel: it Case Study of Social Movement Indonesia. Sementara itu, tulisan proyek, beberapa tulisan yang ada diantaranya: Nina H. Lubis" Banten dalam Pergumulan Sejarah: Sultan, Ulama, Jawara” (2003), “Sejarah Kabupaten Lebak" (2006); dan lain-lain.

${ }^{6}$ Pada akhir 2009 Provinsi Banten bertambah dua wilayah kota administratifnya, yaitu pada November 2007 Kota Serang, dan pada 26 November Kota Tangerang Selatan. Pembentukannya berdasarkan UU No. 32 Tahun 2007 tentang Pembentukan Kota Serang, dan UU No 51 Tahun 2008 tentang Pembentukan Kota Tangerang Selatan sebagai Daerah Otonom, dan setahun kemudian dilantik Pjs. Walikota oleh Kementrian Dalam Negeri.

${ }^{7}$ Riset ini masih berjalan, analisis tentang keterkaitan penataan daerah dan hubungannya dengan etnisitas dan kelas sosial belum dapat disampaikan dalam makalah ini. Penulis masih membutuhkan data-data pendukung untuk analisis ini. 


\section{REFERENSI}

ADB. (1999). Asian Development Bank Outlook 1999. Oxford: Oxford University Press.

Azra, Azyumardi (2002). Hitoriografi Islam Kontemporer: Wacana, Aktualitas, dan Aktor Sejarah. Jakarta: Gramedia.

Badan Pusat Statistik. (2005). Banten dalam Angka 2005. Serang: BPS.

Cartesao, Armando (1944). The Suma Oreintal of Pires, Jilid 2. London: The Hakluyt Society, dalam "Banten Sebelum Islam” Ayatrohaedi dalam Sri Sutjianingsih (ed.). Banten Kota Pelabuhan Jalan Sutra: Kumpulan Makalah Diskusi. Jakarta: Departemen Pendidikan dan Kebudayaan RI.

Chaniago, A. Andirnof (2003). Gagalnya Pembangunan: Kajian Ekonomi Politik terhadap Akar Krisis Indonesia. Jakarta: LP3ES.

Djajadiningrat, Hoesein (1983). Tinjauan Kritis tentang Sejarah Banten. Jakarta: Djambatan dan KITLV.

Djiwandono, J. Soedradjat (2000). "Bank Indonesia and the Recent Crisis", Bulletin of Indonesia Economic Studies, Vol. 36 (1).

Guillot, Claude et.al. (1994). Banten Sebelum Zaman Islam: Kajian Arkeologi di Banten Girang 932 (?) - 1526. Yogyakarta: Pusat Penelitian Arkeologi Nasional dan Ecole Francaise d'Extreme-Orient.

Hill, Hall (2000). The Economy in Crisis Causes, Consequences and Lessons. Singapura: ISEAS.

Jackson, Karl D. (1999). “Introduction: The Roots of the Crisis, dalam Karl D Jackson (ed.). Asian Contagion: The Causes and Consequences of a Financial Crisis. Colorado: Westview Press.

Kahin, George McTurnan (1995). Refleksi Pergumulan Lahirnya Republik: Nasionalisme dan Revolusi di Indonesia (penerjemah Nin Bakdi Soemanto). Solo: UNS Press dan Sinar Harapan.

Kartodirdjo, Sartono (1984). Pemberontakan Petani Banten 1888. Jakarta: Pustaka Jaya.
Kompas, 11 Februari 2000

Kompas, 13 September 2000

Kompas, 2 Agustus 1999

Kompas, 21 Februari 2000

Kompas, 21 Maret 2000

Kompas, 22 Februari 2000

Kompas, 23 Februari 2000

Kompas, 27 Januari 2000

Kompas, 27 Maret 2000

Kompas, 3 Februari 2000

Kompas, 3 Maret 2000

Kompas, 4 Februari 2000

Kompas, 5 Juli 1999

Kompas, 7 April 2000

Kompas, 7 Agustus 1999

Kompas, 9 Februari 2000

Kompas, 9 Maret 2000

Kurosawa, Aiko (1993). Mobilisasi dan Kontrol. Jakarta: Grasindo.

Lapian, A. B. (2004). "Banten”. Naskah Laporan (tidak diterbitkan).

Lapian, A. B. (1992). “Sejarah Nusantara Sejarah Bahari”. Pidato Pengukuhan Guru Besar Luar Biasa FSUI.

Lubis, Nina H. (2003a). Banten dalam Pergumulan Sejarah: Sultan, Ulama, Jawara. Jakarta: LP3ES.

Lubis, Nina H. (2003b). Sejarah Kota-Kota di Jawa Barat. Bandung: Alqoprint.

Michrob, H. \& Chudori, A. M. (1993). Sejarah Perkembangan Arsitektur Kota Islam Banten; Suatu Kajian Arsitektural Kota Lama Banten Menjelang Abad XVI sampai dengan XX. Jakarta: Yayasan Baluwati.

Nakamura, Mitsuo (1988). Jenderal Imamura dan Periode Awal Pendudukan Jepang. Jakarta: YOI.

Oppenheimer, Stephen (2001). Eden in the East: The Drowned Continent of Southeast Asia. Phoenix: paperback.

Radar Banten, 2, 5, 8, 18 Mei 2007

Roesjani, Tb. (1954). Sedjarah Banten. Jakarta: Arief.

Semah, F et.al. (1990). Mereka Menemukan Pulau Jawa. Jakarta: Pusat Penelitian Arkeologi 
Nasional dan Museum National d'Histoire Naturelle.

Setia, Bambang Budi (2002). "Masjid Agung Banten: Bukti Kejayaan Kesultanan Banten”, Kompas, 2 Juni 2002.

Soeara Merdeka, 9 Oktober 1945

Syafrudin, Ateng, et.al. (1993). Sejarah Pemerintahan di Jawa Barat. Bandung: Pemda Tingkat I Jawa Barat.

Thee Khian Wie (2004). Pembangunan, Kebebasan, dan "Mukjizat" Orde Baru: Esaiesai. Jakarta: Kompas \& Freedom Institute.

Tim Penyusun (2003). Sistem Informasi dan Dokumentasi Penataan Ruang Wilayah Tengah Buku Profil Penataan Ruang Propinsi Banten. Jakarta: Depkimpraswil.

Tim Penyusun Subdin Kebudayaan (2003). Profil Seni Budaya Banten. Serang: Dinas Pendidikan Provinsi Banten.

Tjandrasasmita, Uka (2000). Pertumbuhan dan Perkembangan Kota-kota Muslim di Indonesia dari Abad XIII sampai XVIII Masehi. Kudus: Menara Kudus.

Utomo, Djoko (1997). "Banten dalam Sumber Arsip: Suatu Pengamatan Awal," dalam Sri Sutjianingsih (ed.). Banten Kota Pelabuhan Jalan Sutra: Kumpulan Makalah Diskusi. Jakarta: Departemen Pendidikan dan Kebudayaan RI.

Wertheim, W. F. (1958) The Indonesian Town Studies in Urban Sociology. The Haque: W. van Hoeve Ltd.

Wignjosoebroto, Soetandyo (2004). Desentralisasi dalam Tata Pemerintahan Kolonial Hindia Belanda: Kebijakan dan upaya sepanjang babak akhir kekuasaan kolonial di Indonesia (1900-1940). Malang: Bayumedia.

Wijono, Radjimo S. \& Tandiono, Bawor P. (2004). Bermain Kayu Pembangunan: Potret Kotor Industrialisasi di Jawa. Semarang: LBH Semarang, Mesias Fokalis.

https://www.bantenprov.go.id/, diakses pada 24 Januari 2007.

\section{Wawancara}

KH. Encep Badruzzaman Raffly, tokoh masyarakat Pandeglang, 20 Mei 2007.

Tohir (83 tahun), pelaku sejarah, 2 Mei 2005. 